\title{
Seismic investigations of the Ringkoebing-Fyn High on Langeland, Denmark*
}

\author{
J. BIALAS, E.R. FLUEH ** and W. JOKAT *** \\ Institute for Geophysics, University of Kiel, D-2300 Kiel (F.R.G.)
}

(Received February 10, 1989; revised version accepted July 6, 1989)

european

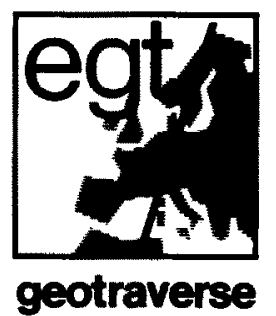

\begin{abstract}
Bialas, J., Flueh, E.R. and Jokat, W., 1990. Seismic investigations of the Ringkoebing-Fin High on Langeland Denmark. In: R. Freeman and St. Mueller (Editors), The European Geotraverse, Part 6. Tectonophysics, 176: $25-41$.

A seismic refraction profile across Langeland (Denmark) obtained from land stations recording airgun shots allowed to resolve upper crustal velocities to a depth of $8 \mathrm{~km}$. The profile traverses the proposed Caledonian Deformation Front and the Ringkoebing-Fyn High. The Ringkoebing-Fyn High is about $10 \mathrm{~km}$ wide and the top basement lies less than $2 \mathrm{~km}$ below the surface Basement velocities as high as $6.4 \mathrm{~km} / \mathrm{s}$, at depths between 6 and $8 \mathrm{~km}$, can be best explained by compositional changes between adjoining basement units to the north and south. South of the Ringkoebing-Fyn High another high velocity basement unit is encountered and most probably represents a basement affected by the Caledonian orogeny. Along this profile on Langeland the positions of the Caledonian Deformation Front and the northern limit of the Zechstein deposits coincide.
\end{abstract}

\section{Introduction}

In June/July 1984 seismic measurements were carried out in southwestern Sweden, Denmark and northernmost F.R. Germany to study the Earth's crust in the transition zone between the Baltic Shield and Variscan Europe. This survey was part of the European Geotraverse (EGT) Project (Mueller and Banda, 1983; Galson and Mueller, 1986) and was named EUGENO-S (from EUropean GEotraverse Northern SegmentSouthern Part). Within EUGENO-S, explosions and airgun shots were recorded on six profiles

* Publication No. 372 of the Institute for Geophysics, University of Kiel.

** Now at GEOMAR, Research Center for Marine Geosciences, Wischofstr, 1-3, D-2300 Kiel (F.R.G.).

*** Now at Alfred Wegener Institute, Columbusstr., D-2850 Bremerhaven (F.R.G.). crossing the major tectonic lineaments. First results and the details of the field operation are given by Flueh and Berthelsen (1986), Bialas (1987), Gregersen et al. (1987), Moeller (1987), EUGENO-S Working Group (1988), Green et al. (1988), and Kioerboe (1988). Profile 1 of the EUGENO-S survey starts in the southwest in Schleswig-Holstein and runs in a northeastern direction across Sealand onto the Baltic Shield in southwestern Sweden (Fig. 1). In this paper we describe the results of a detailed investigation of the part of this profile that traverses the Ringkoebing-Fyn High (RFH) on the island of Langeland.

As shown in Fig. 2, seventeen recording instruments were deployed on Langeland and recorded airgun shots fired along an approximately $100 \mathrm{~km}$ long line parallel to the coast of the island. Due to the limited energy of the airgun shots, the high noise level, and the strong absorption within the 


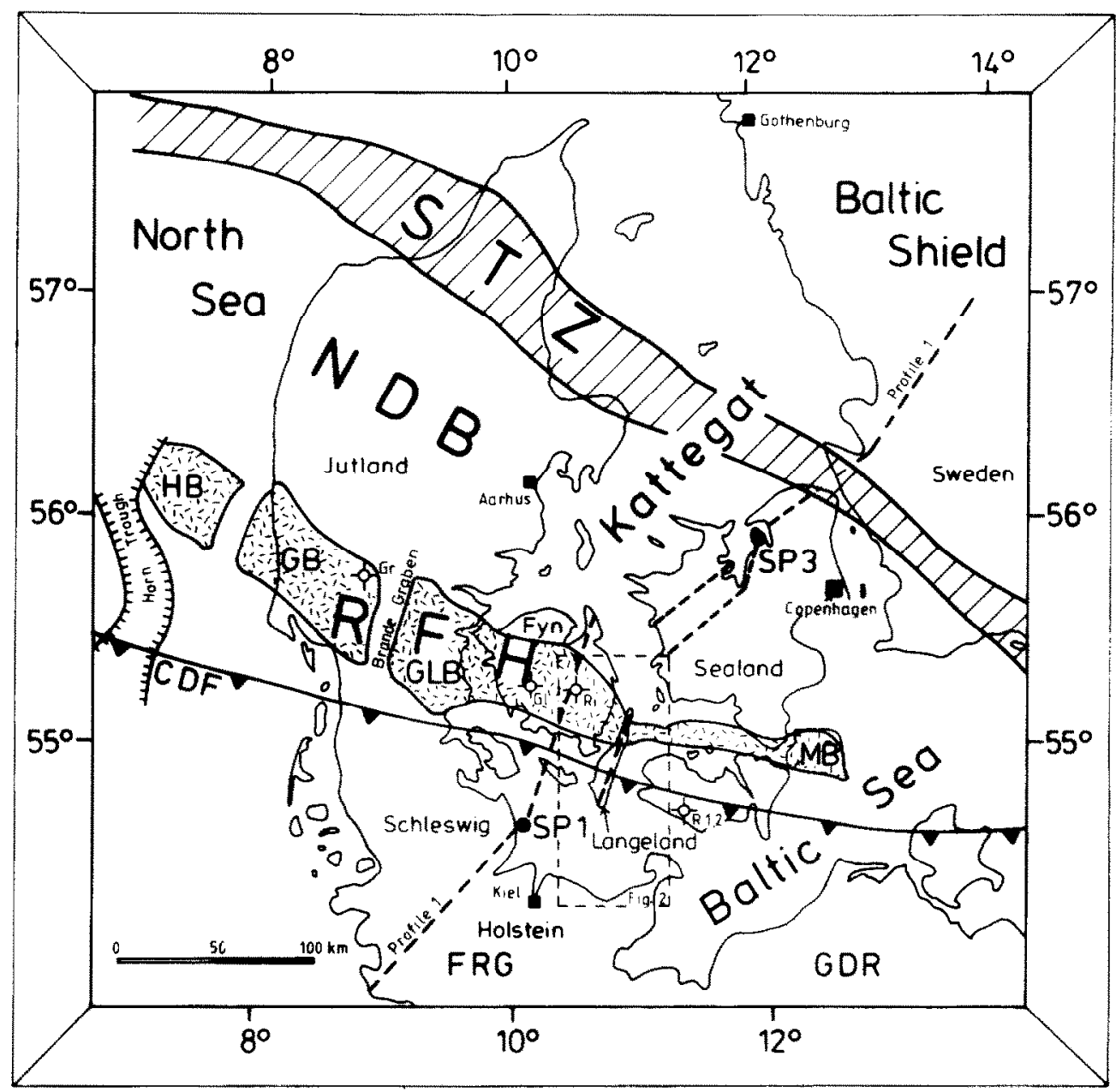

Fig. 1. Structural map of Denmark and surrounding regions (modified from EUGENO-S Working Group, 1988). $S T Z=$ Sorgenfrei Tornquist Zone; $N D B=$ Norwegian Danish Basin; $R F H=$ Ringkoebing-Fyn High; $C D F=$ Caledonian Deformation Front. The Ringkoebing-Fyn High comprises the Holmsland $(H B)$, the Grinsted $(G B)$, the Glamsbjerg $(G L B)$, and the Moen Blocks (MB). Exploratory wells $(G R=$ Grinsted; $R i=$ Ringe; $G l=$ Glamsbjerg; $R I, 2=$ Roedby 1 and 2$)$ mentioned in the text. The receiver locations along profile 1 are marked by a stippled line.

sediments, signals could only be detected to maximum distances of $35 \mathrm{~km}$, thus providing only information on sedimentary layers, basement and upper crust. Nevertheless, the high multiplicity of the observed phases (up to 5 fold) allows for a detailed analysis of lateral variations within the basement.

\section{Geological setting}

The Ringkoebing-Fyn High in southern Denmark consists of a number of elevated basement blocks, reaching 1 to $2 \mathrm{~km}$ below the surface (Fig. 1). The Ringkoebing-Fyn High is bounded by two deep sedimentary basins in the south and north. To the north, within the Norwegian Danish Basin (NDB) Mesozoic sequences (mainly Triassic sediments), reach a maximum thickness of more than $8 \mathrm{~km}$ (Bertelsen, 1980; Michelsen and Andersen, 1981). They are underlain by tilted CambroSilurian sediments, which have been encountered in deep wells in Jutland (Liboriussen et al,, 1987). The Norwegian-Danish Basin is bounded to the north and east by the Sorgenfrei Tornquist Zone (EUGENO-S Working Group, 1988).

South of the Ringkoebing-Fyn High in the North German Lowlands the Mesozoic sequences in Schleswig-Holstein vary in thickness between 5 


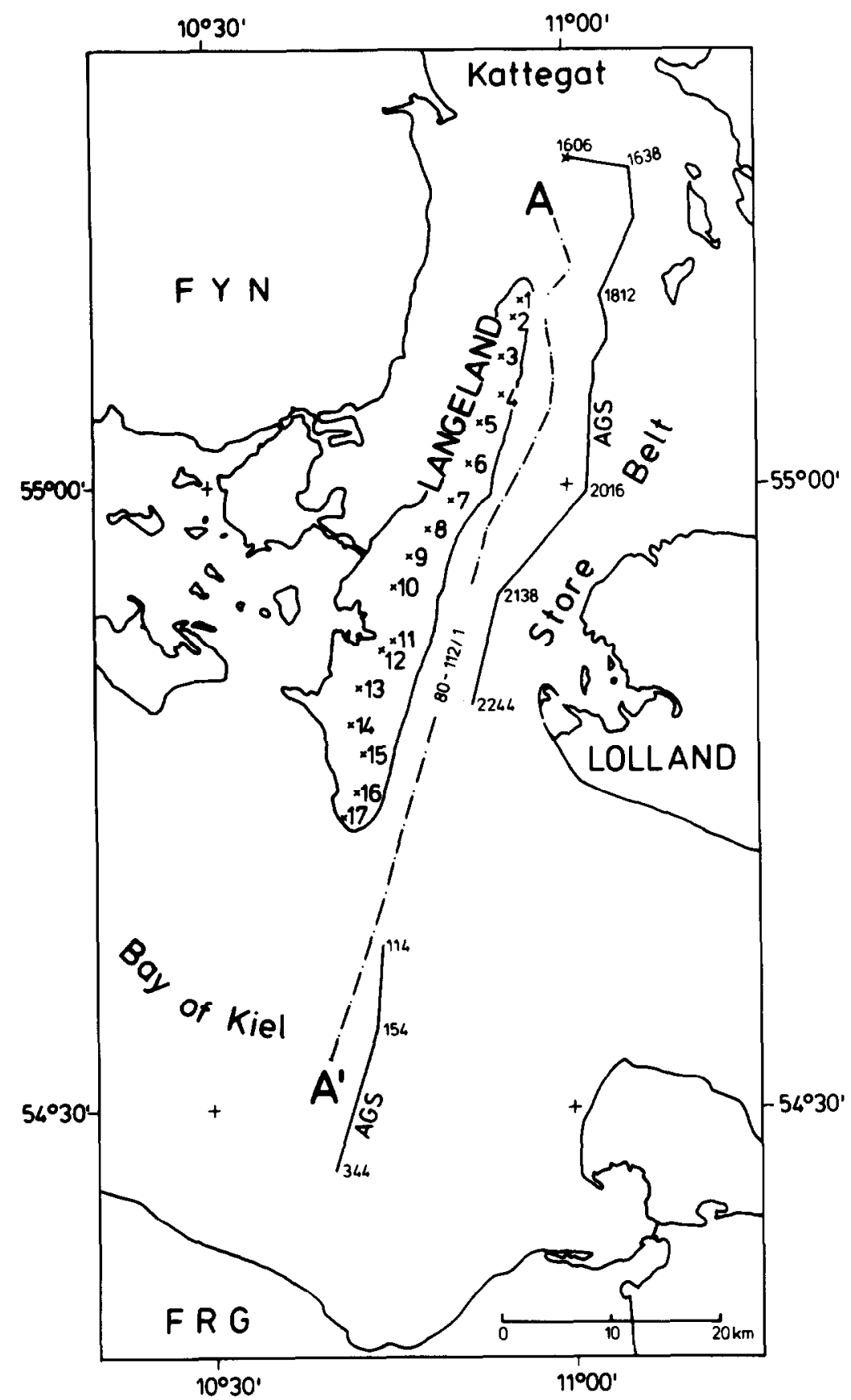

Fig. 2. Detailed location map of the area under investigation. The airgun shots (AGS) are numbered according to the time of day they were fired. $A-A^{\prime}$ denotes the reflection profile $80-112 / 1$.

and 12 km (Ziegler, 1982; Best et al., 1983). They are underlain by a several kilometers thick sequence of Devonian and Carboniferous sediments (Ziegler, 1984), that rest upon a Caledonian metamorphosed and deformed basement. The northern limit of the so-called North German-
Polish Caledonides, which was inferred from core studies of exploratory wells in the North Sea and south of the Ringkoebing-Fyn High on land (Frost et al., 1981; Ziegler, 1982; Liboriussen et al., 1987), is indicated as the Caledonian Deformation Front (CDF) in Fig. 1. It was one of the purposes of this 
investigation to see if the Caledonian basement has a distinct seismic signature which could help to delineate its northernmost position in this area.

The Ringkoebing-Fyn High, first described by Sorgenfrei and Buch (1964), consists of a series of elevated basement blocks, extending from the North Sea across Denmark into the Baltic Sea. Individual blocks are separated by $\mathrm{N}-\mathrm{S}$ trending grabens or troughs, such as the Brande Trough in Jutland between the Grinsted and Glamsbjerg Blocks. Precambrian basement has been drilled at $1600 \mathrm{~m}$ in the Grinsted and at $840 \mathrm{~m}$ in the Glamsbjerg wells (Larsen, 1971; for location see Fig. 1 and 2). The blocks were uplifted relative to the adjoining basins in Late Carboniferous-Early Permian times. Throughout the literature different sets of contours for the Ringkoebing-Fyn High are seen. Some of them are based on the limits of the Zechstein transgression (cf. Bertelsen, 1980), while others are deduced from the associated gravity high (20-40 mGal Bouguer anomaly; EUGENO-S Working Group, 1988). Following the second approach, we have adopted the contours as shown by Michelsen (1978), see Fig. 1.

For a full treatment of the geology and the tectonic development of this area the reader is referred to EUGENO-S Working Group (1988).

\section{Field work}

The seismic measurements were carried out on June $18 / 19$ th, 1984 . The position of the recording stations and the locations of the airgun shots are shown in Fig. 2. Altogether 17 MARS 66 instruments (Berckhemer, 1970) were operated on Langeland, while other instruments, not considered here, were at the same time deployed to the east on Sealand. The airgun shots were fired from aboard the R.V. "Poseidon", which sailed for 12 hours from north to south starting in Kattegat, through Store Belt into the Bay of Kiel.

The ship's speed was 5 knots; shots were fired every $2 \mathrm{~min}$, thus achieving a shot spacing of 300 $\mathrm{m}$. In total, 4 airguns of 8 litres each were fired simultaneously at a depth of $10 \mathrm{~m}$. The shotbreaks were controlled by a radio time signal, identical to the time signal used by the land stations. For security reasons the airguns could not be con- tinously operated in the southern part, causing a gap of $25 \mathrm{~km}$ in the shooting line between SP 2244 and SP 114. Besides the airgun shots, the stations also recorded two explosions. One explosion was fired in the Bay of Kiel (SP 1) and was observed to distances of 40 to $80 \mathrm{~km}$, while the other shot SP3) was fired on Sealand (for locations see Fig. 1) and observed from 100 to $150 \mathrm{~km}$.

As can be seen from Fig. 2, the distances between the airgun shots and the receivers range from 7 to $80 \mathrm{~km}$, thus information about the uppermost velocity field to a depth of $2-3 \mathrm{~km}$ is not available from these data. Also, clear signals could only be recorded successfully to a maximum distance of $35 \mathrm{~km}$. Therefore only information concerning a depth range of $2-10 \mathrm{~km}$ can be gained from the refraction data. However, additional constraints on the shallow structure are available from several commercial reflection profiles, such as the reflection line $80-112 / 1$, the location of which is shown in Fig. 2. This profile was recorded by Prakla-Seismos AG in 1980 for Dansk Boreselskab A/S (Mærsk Olie and Gas $\mathrm{A} / \mathrm{S}$ ) and has now been released to the Danish public domain.

The reflection line $80-112 / 1$ is about $80 \mathrm{~km}$ long and runs approximately $\mathrm{N}-\mathrm{S}$ close to the coast of Langeland (Fig. 2). The reflection section is shown together with an interpretive cross-section in Fig. 3. It represents a 48-fold stack, the cdp-spacing is $12.5 \mathrm{~m}$. Conventional processing, such as debubbling, deconvolution, filtering and velocity analysis was applied to the data. The recording length is $4 \mathrm{~s}$, although only within the first $2 \mathrm{~s}$ are clear reflections visible. The interpretation, as shown in the bottom of Fig. 3, is based on correlations to the nearest boreholes (Glamsbjerg, Ringe and Roedby shown in Figs. 1 and 2 and summarized in the Well Data Summary Sheets (Vol. 2, 1981) of the Geological Survey of Denmark), the interval velocities and the general knowledge of the sedimentary layers (Ziegler, 1982, $1984)$. Three to four major sequences can be recognized from the reflection section. Reflection $A$ marks the top Danian near the base of the Tertiary at a depth between $0.1 \mathrm{~s}$ in the north and 0.4 $\mathrm{s}$ in the south. Reflection $B$ between 0.4 and $0.7 \mathrm{~s}$ $(0.4$ to $0.8 \mathrm{~km})$ corresponds to the base of the 

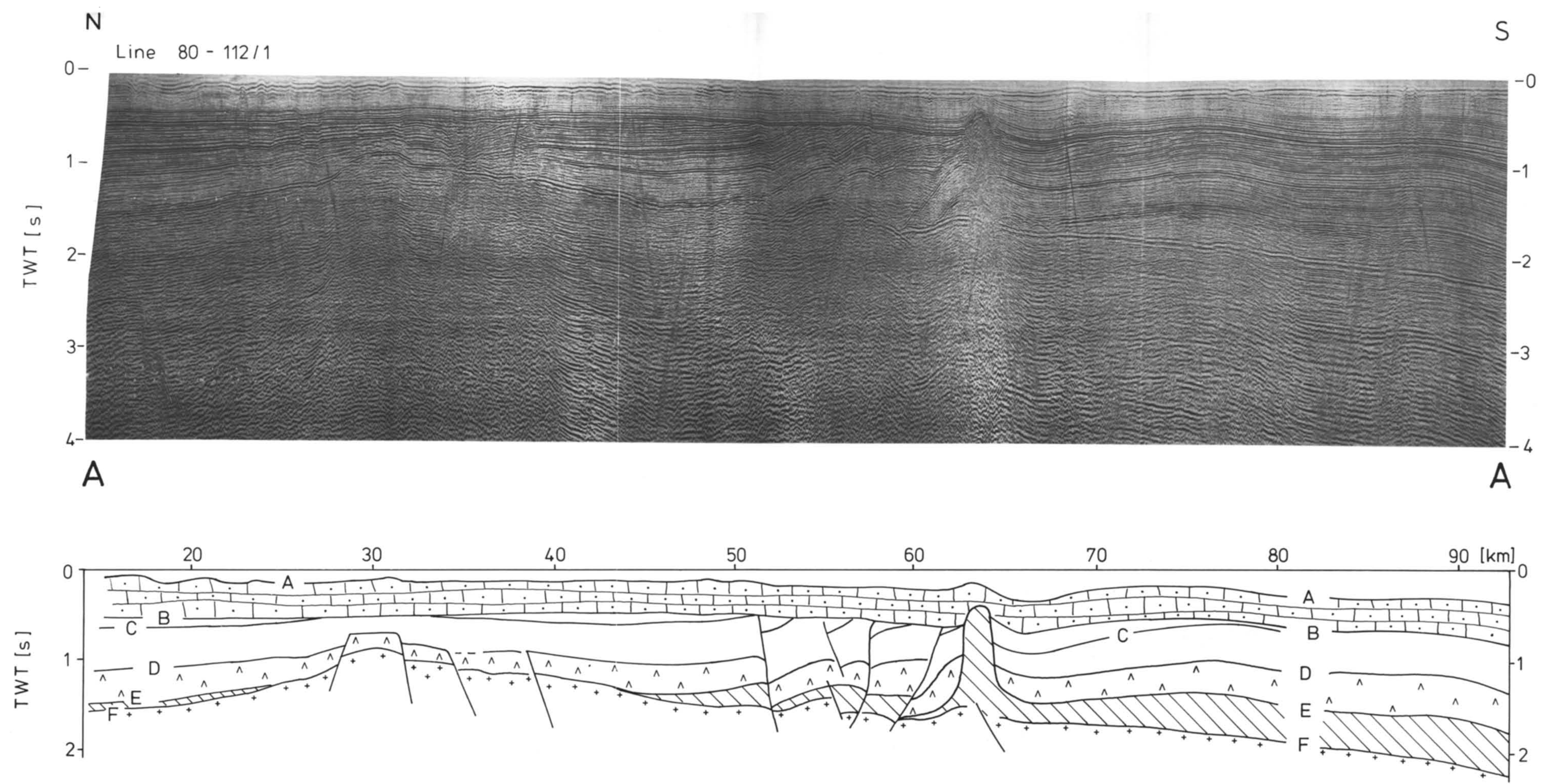

Chalk $\quad \square$ Lower Triassic $\square$ zechstein $+{ }^{+}$Basement

Fig. 3. top: reflection line 80-112/1, for location see Fig. 2; bottom: interpretative section of the data above; for discussion see text. 


\section{E U GENO-S}
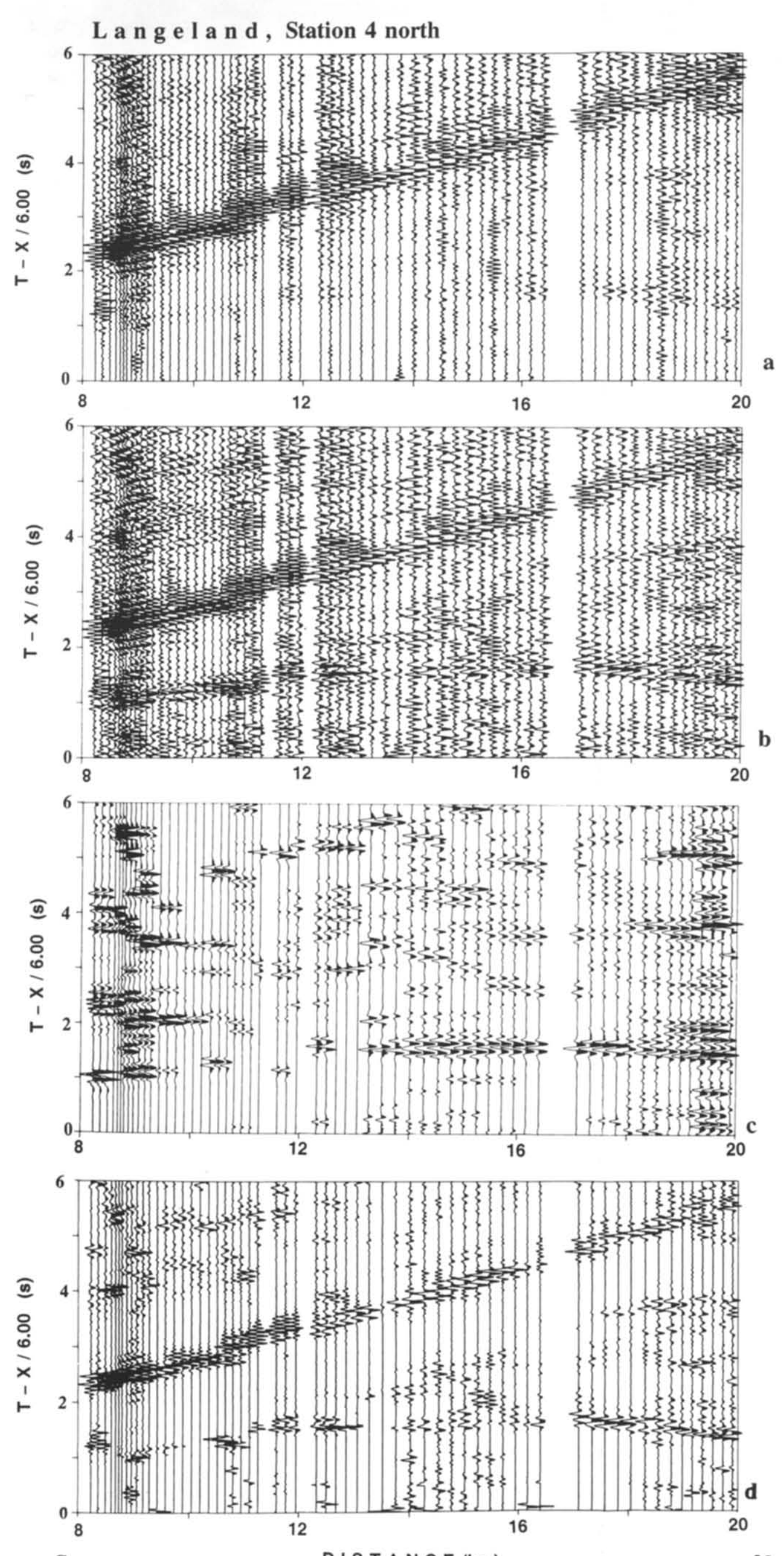

$\mathrm{S}$

DIS T A N CE $(\mathrm{km})$

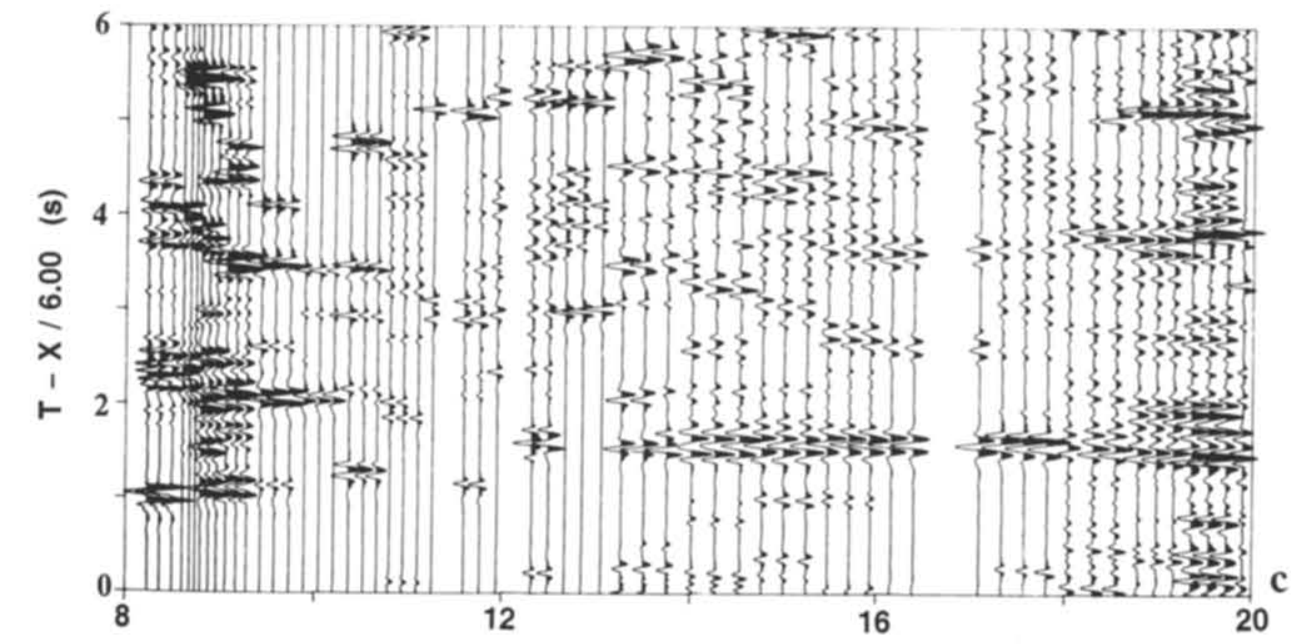

\section{E U G E N O - S}

$L$ a $n$ g e I a n d, Station 11 north

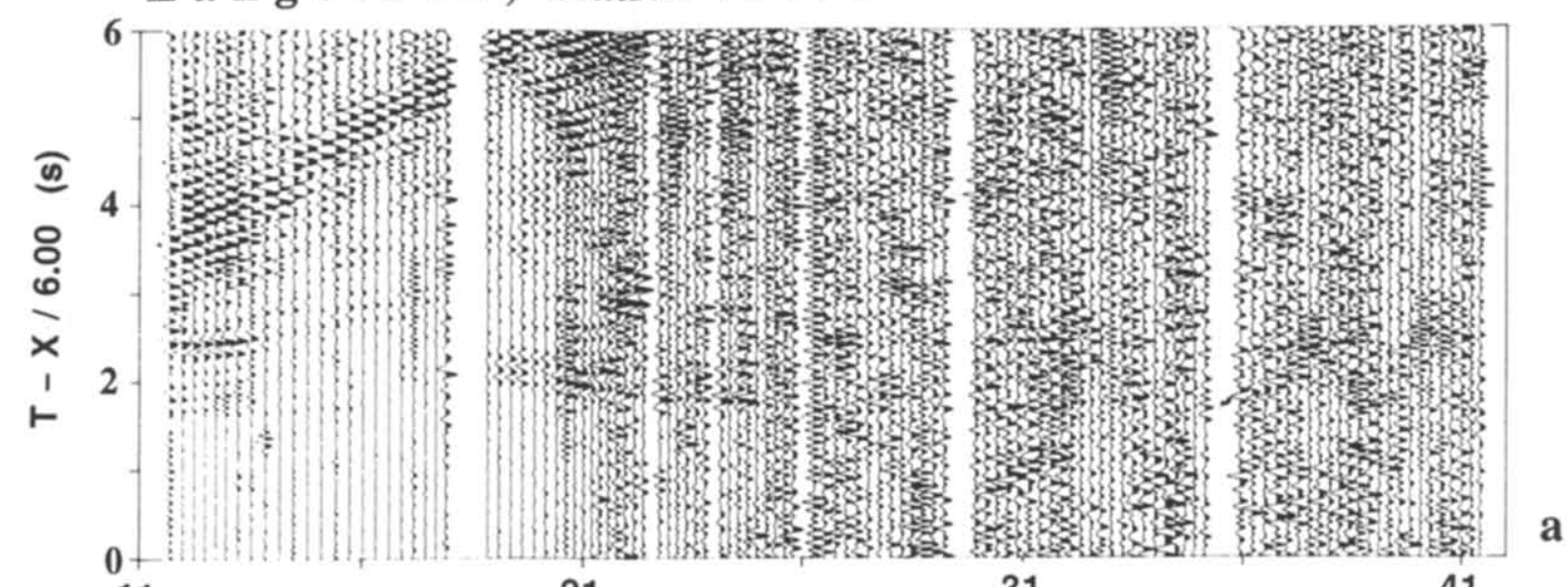

$0+$

21
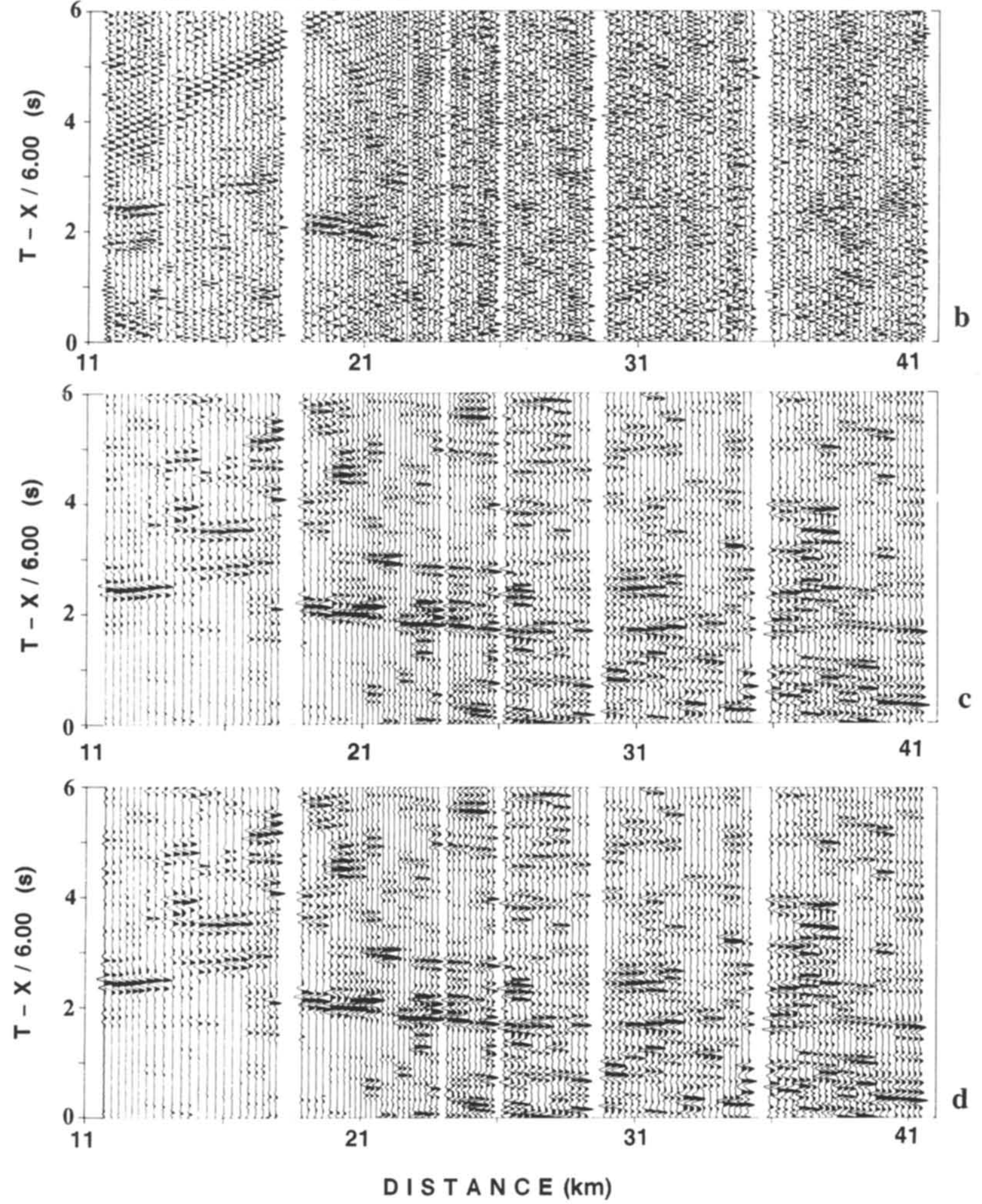

Fig. 4. Record section from Station 4-north, vertical component. a. Trace-normalized section, bandpass filtered 4-16 $\mathrm{Hz}$. b. AGC-scaled $(2 \mathrm{~s})$ section, bandpass filtered $4-16 \mathrm{~Hz}$. c. Slant-stack with with 50 slants between 3.5 and $10 \mathrm{~km} / \mathrm{s}$ over 5
semblence cutoff below 0.25 . d. ECG-section using 3 traces and a window of $120 \mathrm{~ms}$. The reduction velocity is $6 \mathrm{~km} / \mathrm{s}$. 
chalks (Lower Cretaceous). The top Triassic is also seen as a prominent reflection $(C)$ and shows a number of faults in the middle part of the line. The Triassic is further subdivided by reflection $D$ which delineates the Top Oerslev formation (Upper Lower Triassic). In the southern part the top Zechstein reflection $(E)$ is evident above the basement $(F)$. It is highly disturbed between $\mathrm{km} 50$ and 65 , where a small salt diapir and further north two distinct faults are seen. The rise of the diapir has affected the layers above, and the basement reflection below the diapir is also less clear. There may be faults in the basement here, connected to the development of the salt structure. The Zechstein pinches out against the basement at $\mathrm{km} 50$. There is no clear evidence for a Caledonian deformed basement from this data set. However, the normal faults between $\mathrm{km} 50$ and $\mathrm{km} 60$ may be indicative for the position of the Caledonian Deformation Front.

\section{Processing of the refraction data}

All land stations were equipped with a threecomponent seismometer. The recordings were digitized with a sampling interval of $2 \mathrm{~ms}$. A frequency analysis led to subsequent bandpass filtering of 4-16 $\mathrm{Hz}$ to improve the signal-to-noise ratio. For display, all record sections were reduced at 6 $\mathrm{km} / \mathrm{s}$, and examples are shown in Figs. $4 \mathrm{a}$ and 5a. It is commonly observed on the record sections that the first arrivals drop below the average noise level at distances between 25 and $37 \mathrm{~km}$. The apparent velocities of the first arrivals vary between 3 and $7 \mathrm{~km} / \mathrm{s}$, indicating strong lateral inhomogeneities. High amplitude surface waves dominate in the later parts of the record sections at shorter distances. Therefore, on trace-normalized record sections the first arrivals appear rather weak. However, they are much stronger if AGCscaling is applied (Figs. 4b and 5b). For further enhancement of the signals and to help with the correlation we have applied velocity filters. Since with a shot spacing of $300 \mathrm{~m}$ or less there is no spatial aliasing below $10 \mathrm{~Hz}$, we can apply whole wavefield slant stacks and local slant stacks in the delay time-slowness $(\tau-p)$ domain, using the algorithms described by Jokat (1986), and shown by
Jokat and Flueh (1987). Examples of the slant stacks are shown in Figs. $4 \mathrm{c}$ and $5 \mathrm{c}$. In the Slant Stacks some high amplitude later arrivals occur. They are caused by low velocity/high amplitude surface waves, which do not meet the spatial aliazing limit. Additional information is available from the "Energy Controlled Gain" sections (ECG, Bittner et al., 1987), as shown in Figs. 4d and 5d.

The horizontal components and consequently the S-wave data are not considered here, since they were contaminated with noise to such a high level that they did not yield any useful information. In addition, $\mathbf{S}$ waves may not have been efficiently generated at the sea bottom or deeper interfaces.

\section{Interpretation}

All record sections were processed as described above, and are collected in Bialas (1987). The arrival times we have picked are summarized in the traveltime diagram in Fig. 6. The apparent velocities range from 3.9 to $7.5 \mathrm{~km} / \mathrm{s}$, with intercept times between 0.2 and $2.6 \mathrm{~s}$. Up to three traveltime branches can be identified at individual stations. The first branch shows velocities ranging from 3.9 to $4.9 \mathrm{~km} / \mathrm{s}$, and correspond to waves being refracted through the Triassic sequences, and in the southern part also through the postCaledonian-Palaeozoic formations. The next branch has velocities between 4.9 and $6.0 \mathrm{~km} / \mathrm{s}$ and are refracted waves from the upper basement. The third traveltime branch is only observed at a few stations at larger offsets, and their apparent velocities are rather scattered, varying between 6.0 and $7.5 \mathrm{~km} / \mathrm{s}$. This phase corresponds to waves being refracted through a high velocity layer at a depth of 6-8 km.

The interpretation was done by forward modeling of the observed traveltimes using the raytracing algorithm described by Luetgert (1988). The lateral offset between the stations and the shooting line is between 7 and $10 \mathrm{~km}$, thus an offset split-spread is recorded for every station. During modelling, the stations were projected onto the shooting line, and a flat segment about $5 \mathrm{~km}$ wide was introduced into the model around the station to account for the lateral offset. This proved to be 


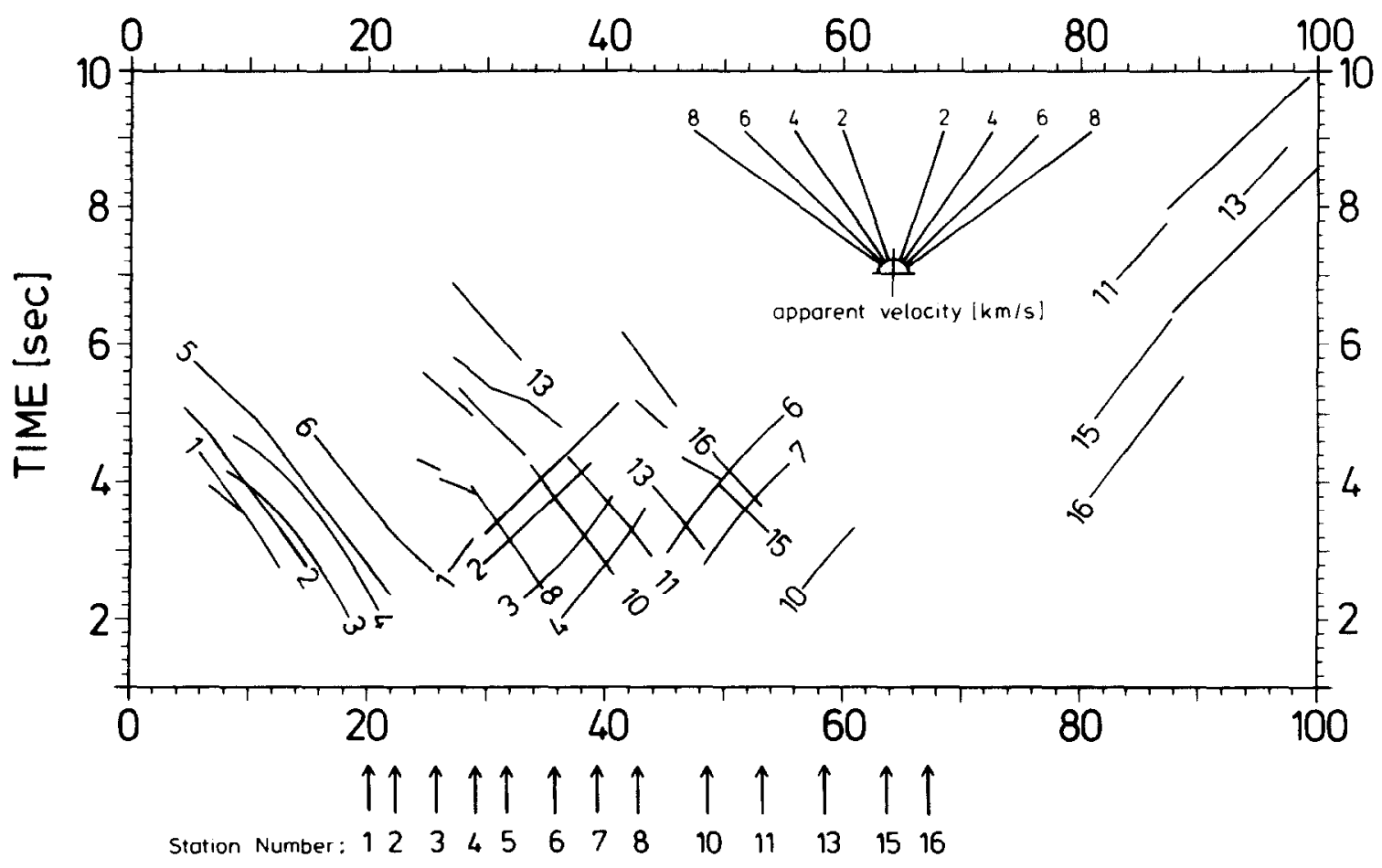

DISTANCE $[\mathrm{km}]$

Fig. 6. Traveltime diagram of all arrivals picked. The locations of the stations that sucessfully recorded airgun shots are projected onto the line and marked by arrows on the bottom. The numbers on the traveltime curves correspond to the station numbers.

a suitable approach, since only minor structural variations are expected along the strike of the Ringkoebing-Fyn High, compared to the lateral variations across the structure. A starting model was generated using both the reflection and refraction data. Theoretical amplitudes were also calculated to prove that the arrivals under consideration have significant amplitudes and can be seen in the noisy data. Since in most record sec- tions only one phase is interpreted and thus no amplitude ratios are obtained for further refinement of the model, they are not included here.

Reflection line 80-112/1 provided structural and velocity control for the sedimentary section, and the layer intercept times of the refraction data were depth converted to constrain the sub-sedimentary structure. Iterative changes of the boundaries and velocities led to the final model

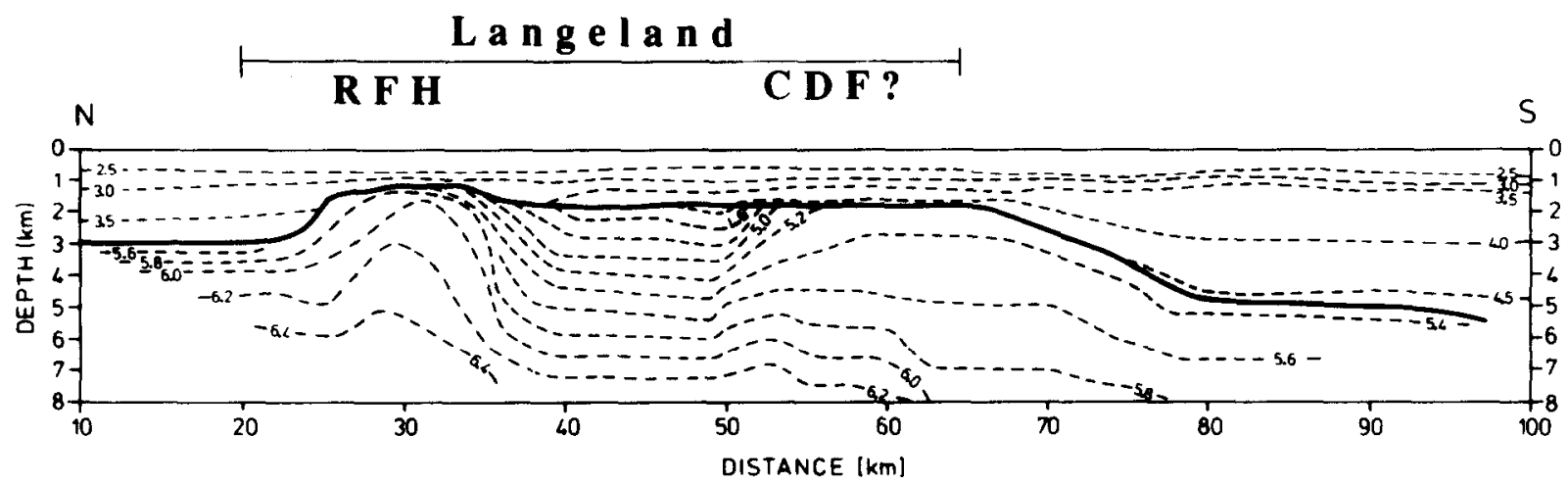

Fig. 7. Velocity contours of the final model, vertical exaggeration $2: 1$. The heavy line delineates the basement. 


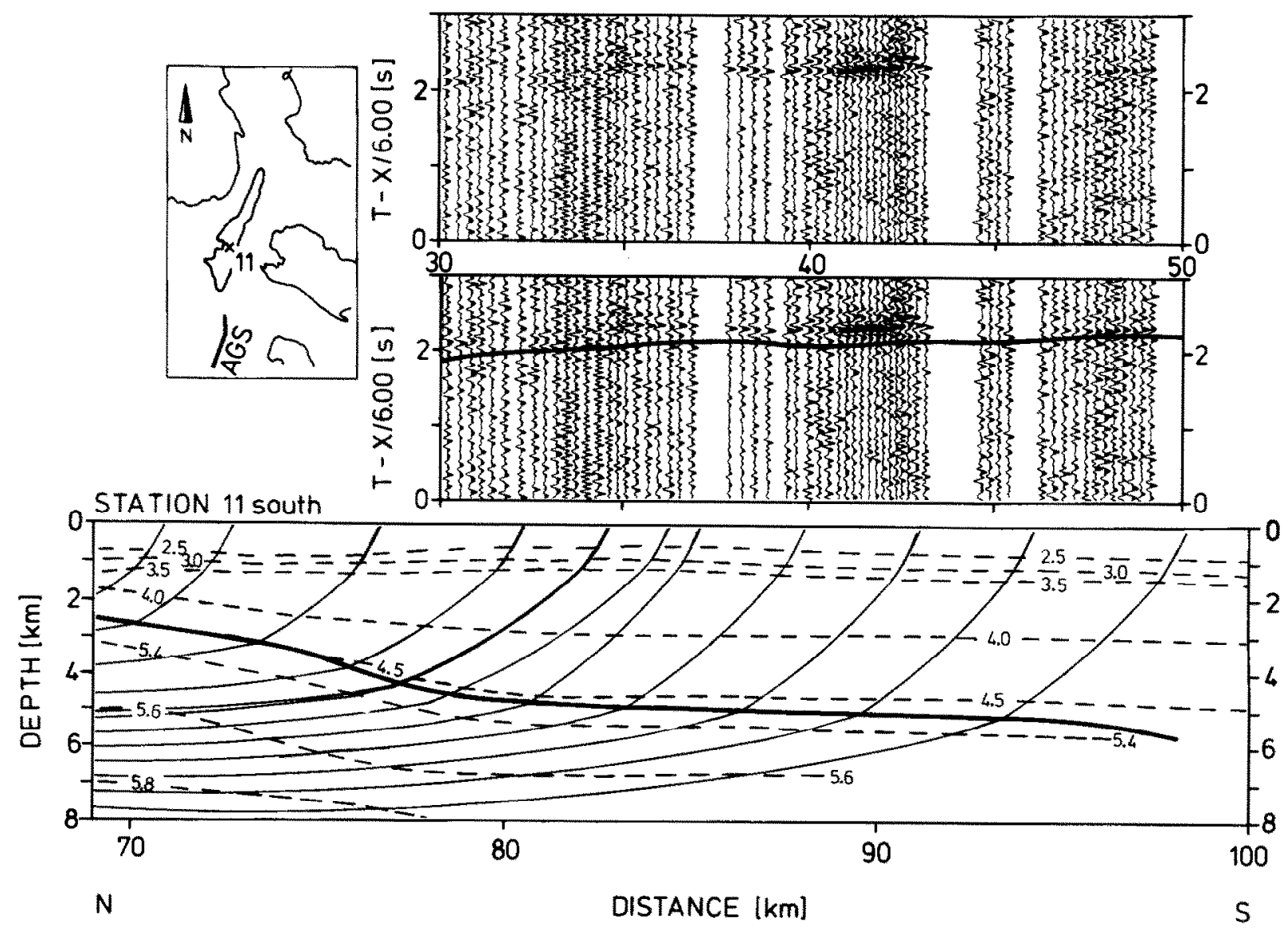

Fig. 8. Record section (top) with calculated traveltimes overlain (middle) and raypaths through the model (bottom) for Station 11 -south. The record sections are reduced with $6 \mathrm{~km} / \mathrm{s}$. The distance labels on the record sections refer to the shot-receiver distance, whereas those on the model refer to Figs, 3,6, and 7.

that fits all observed traveltimes to within $0.2 \mathrm{~s}$. The final two-dimensional velocity model is shown in Fig. 7. Two examples of the raypaths through the model and a comparison of the calculated traveltimes with the observed seismograms are shown in Figs. 8 and 9.

As shown in the model in Fig. 7 , there is considerable lateral velocity variation along the profile. This is clearly indicated by the traveltime diagram in Fig. 6 and was also evident from the record-sections obtained from the explosions at SP1 and SP3 (Gregersen et al., 1987). From SP1 the first arrivals show a pronounced distortion when crossing the northern part of Langeland. Here the arrivals are about $0.6 \mathrm{~s}$ early compared to the southern part of the line. In Fig. 10 the record section is shown together with the raypaths and calculated traveltimes. The relatively small remaining misfit may be due to the fact that SP1 is offset from the line. A similar picture is obtained from the record section from SP3. The $P_{M} P$ shows a rather complex pattern on northern Langeland. In the north, there are at least two possible amplitudes to pick as the $\mathrm{P}_{\mathrm{M}} \mathrm{P}$ (at 2.0 and 2.5 reduced time at $100 \mathrm{~km}$, see Fig. 10). The model indicates that the later phase be identified as the $\mathrm{P}_{\mathrm{M}} \mathrm{P}$, since the upper crustal velocity variations will connect them to the largest amplitudes further south. This is shown in Fig. 10, where the record section and the raypaths and calculated traveltimes of a hypothetical $P_{M} P$ phase from a flat lying Moho are shown.

\section{Discussion}

The model for the upper crust along a line across the Ringkoebing-Fyn High on Langeland is constrained by the observations of airgun shots 

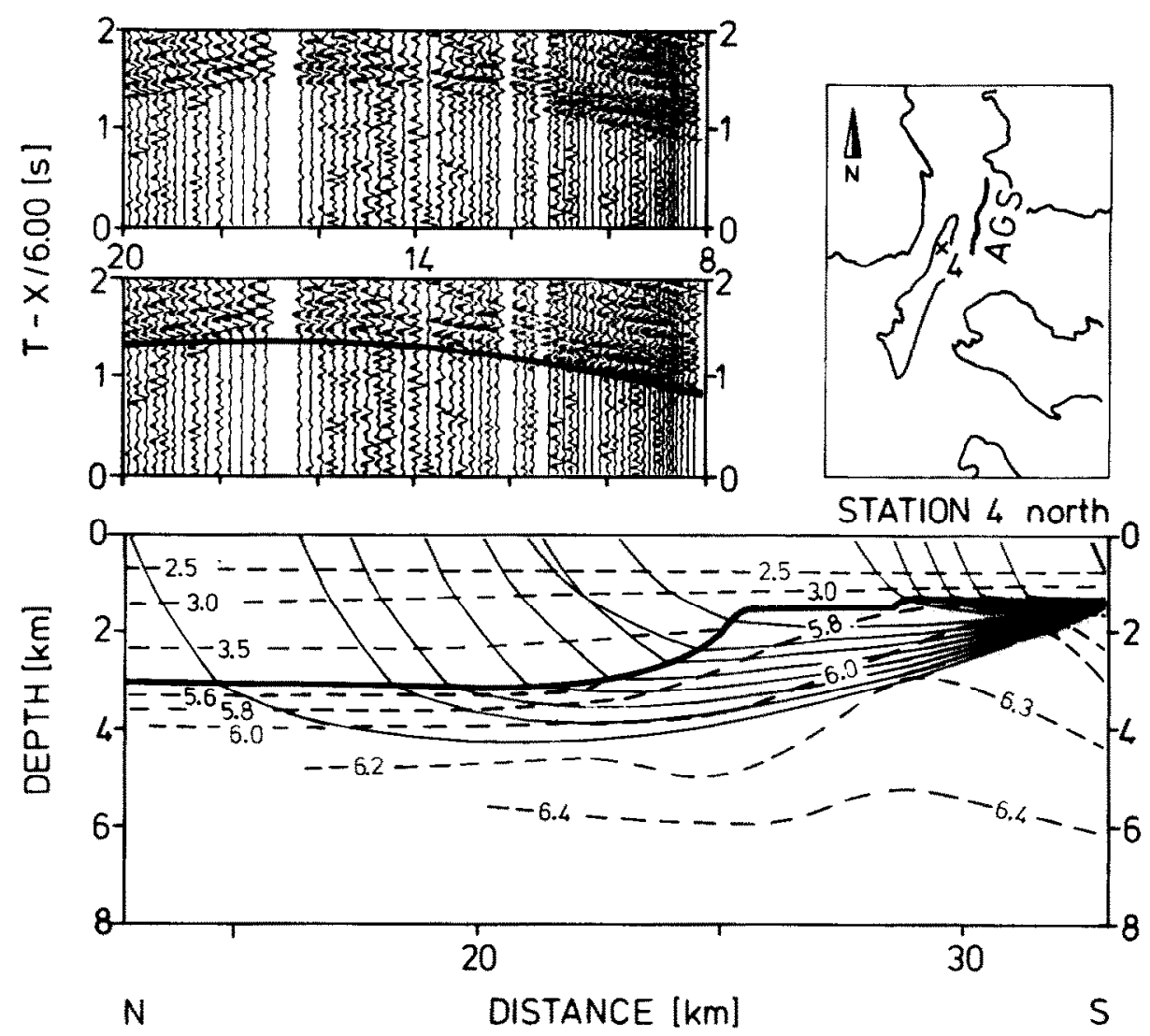

Fig. 9. Record section, traveltimes and raypaths for Station 4-south. Other details as in Figure 8.

and two explosives, matching rather well the observed arrival times. It also fits the observed gravity field, which shows a pronounced high along the strike of the Ringkoebing-Fyn High and a minor high in the southern part of Langeland (Saxov, 1976). The main features of the velocity field in the basement are the two areas of higher velocities. The northern one, centered near $30 \mathrm{~km}$ is about $10 \mathrm{~km}$ wide with velocities as high as 6.4 $\mathrm{km} / \mathrm{s}$ at depths between 6 and $8 \mathrm{~km}$. The top of the basement is at a depth of less than $2 \mathrm{~km}$. However, it is much wider compared to the basement seen on the reflection line (Fig. 3). This indicates the general decrease of the width of the basement high from west to east (see Fig. 1). The model suggests that the high velocities are asymmetrically distributed within this area, but one should keep in mind that the lateral resolution is less than $3 \mathrm{~km}$ (the average station spacing).

The second zone of relatively high basement velocities falls between $\mathrm{km} 50$ and $\mathrm{km} 65$ of the model, where velocities are up to $0.6 \mathrm{~km} / \mathrm{s}$ higher compared to the adjoining area in the north, especially at shallow depth. In this area the reflection line $80-112 / 1$ shows a number of faults reaching into the basement and a small salt diapir on top of a fault. The Zechstein deposits terminate at the northern rim of the high velocity block. It also coincides with the assumed position of the Caledonian Deformation Front as tentatively shown in Fig. 1. It is thus very tempting to relate this high-velocity zone to the Caledonian orogeny, during which high grade metamorphic rocks or basic intrusives have been brought close to the surface.

Earlier interpretations of the crustal structure across Langeland (Moeller, 1987; EUGENO-S Working Group, 1988) only utilized the record sections from the two explosions. In the interpretation shown by Moeller (1987) the basement velocities of the Ringkoebing-Fyn High are higher compared to the adjoining basement in the south but remain constant further north. A major dis- 
Sp 3
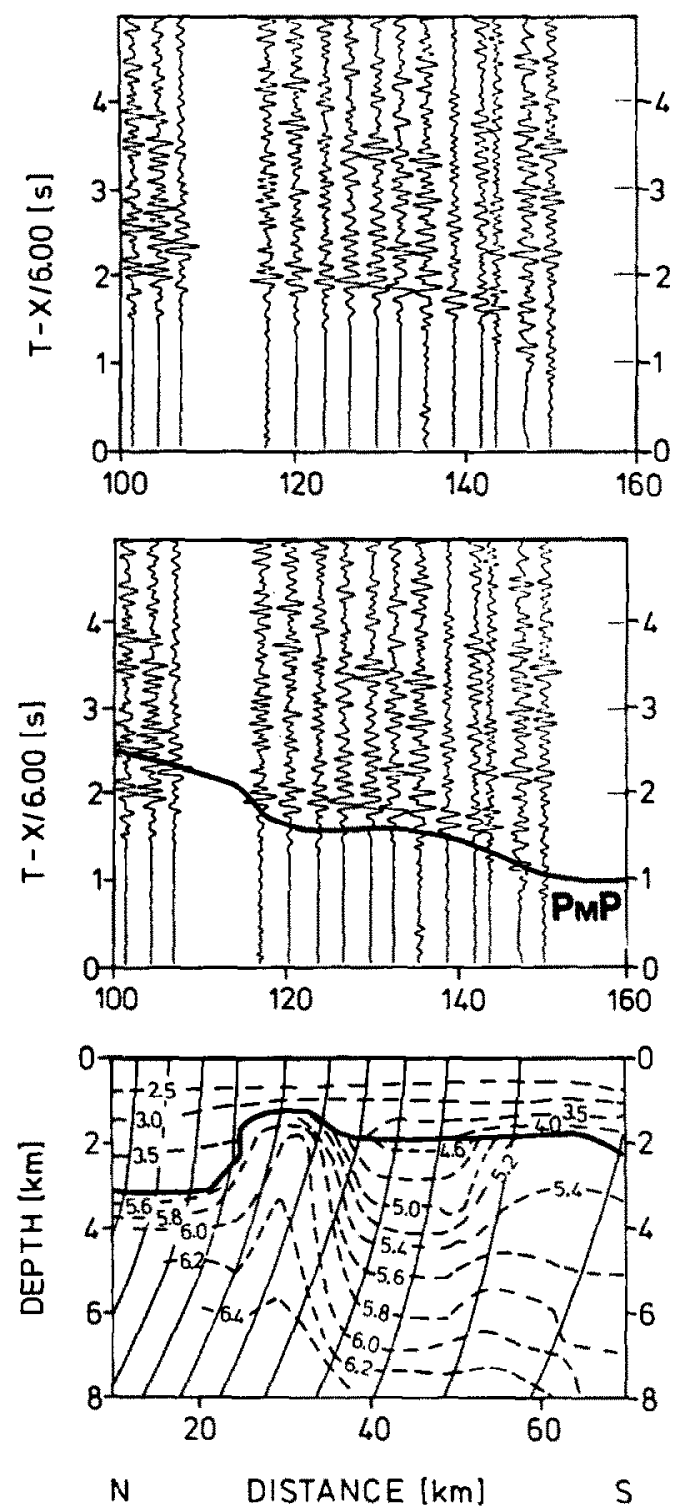

Sp 1
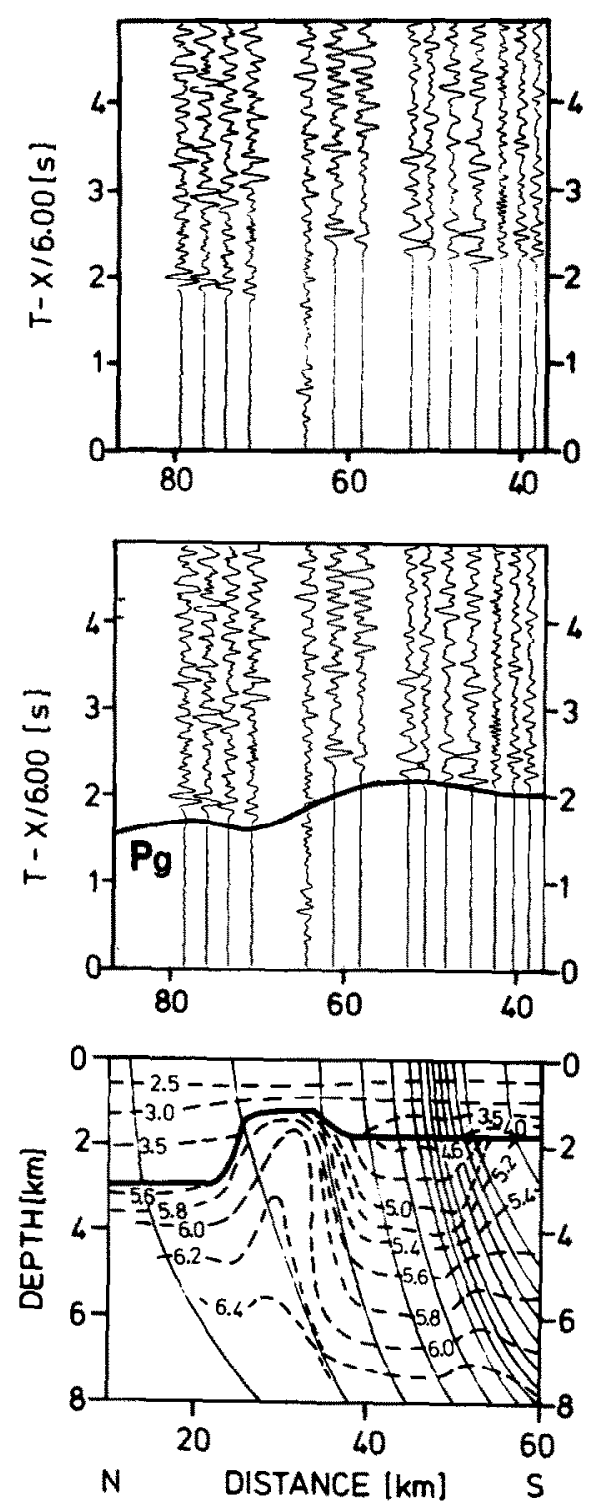

Fig. 10, Left: Record section, traveltimes and raypaths for the $P_{M} P$-phase from SP3 (northern Sealand); right: Record section, traveltimes and raypaths for the Pg-phase from SP1 (Bay of Kiel). Other details as in Fig. 8.

continuity dipping from a depth of $5 \mathrm{~km}$ in the south to $10 \mathrm{~km}$ in the north of Langeland separates the upper crust from the middle crust. This discontinuity could not be constrained from the airgunshot record sections. In addition a small high velocity "plume" is encountered at middle to lower crustal depth. The interpretation of the EUGENO-S Working Group (1988) shows a broad zone of high basement velocities at the northern end of Langeland. The Moho depth is at $33 \mathrm{~km}$ in both interpretations. However, in the interpretation by Moeller (1987) the Moho deepens to the southwest, whereas the EUGENO-S Working Group (1988) suggests that the Moho is more shallow both north and south of the RingkoebingFyn High.

None of the two interpretations took the airgun shots into account. Consequently, they did not 
resolve the details of the upper crustal structure as shown here. The main structure of the model, the two high-velocity blocks sandwiched in between blocks of lower velocities and the general increase of basement depth to the south are well constrained by the multifold airgun-shot observations.

\section{Conclusions}

The seismic investigations across the Ringkoebing-Fyn High on Langeland provided a detailed velocity model for the upper crust between 2 and $8 \mathrm{~km}$ depth. The Ringkoebing-Fyn High in the northern part of Langeland is about $10 \mathrm{~km}$ wide and reaches to less than $2 \mathrm{~km}$ below the surface. In its center the velocities are about $0.5 \mathrm{~km} / \mathrm{s}$ higher compared to the adjoining basement velocities north and south of the high. This velocity variation can only be accounted for by a change in chemical-mineralogical composition. A $10-20 \mathrm{~km}$ wide larvikitic intrusion of Permian age has been suggested to subcrop in the basement surface of the Glamsbjerg Block on Fyn (Holmsen, 1958). The interpretation of profile 5 of the EUGENO-S lines also shows rather high velocities of 6.3 to 6.4 $\mathrm{km} / \mathrm{s}$ at depths between 6 and $10 \mathrm{~km}$ in that region (EUGENO-S Working Group, 1988; Kioerboe, 1988). Thus, a similar or a basic intrusion may be responsible for observed velocities of the Ringkoebing-Fyn High on Langeland.

A second zone of increased basement velocities is found in the southern part of Langeland. This area corresponds to the northern limit of the Zechstein deposits and the basement underneath is seen to be block faulted. However, the top Zechstein may be an erosional surface. It is very tempting to relate this zone and the normal faults to later movements around the Caledonian Deformation Front. If one follows this idea, the position of the Caledonian Deformation Front (see Fig. 1) as previously outlined by EUGENO-S Working Group (1988) is in its correct position. The normal faults would indicate Late Carboniferous and younger reactivation of the Caledonian Deformation Front.

The transition from the low- to high-velocity basement is very narrow ( $>5 \mathrm{~km}$ ). Keeping in the lateral resolution of the seismic data in mind, it could actually be even more narrow and resemble a fault zone separating two distinct basement units. Unfortunately we are unable to show how this zone extends at greater depth and how it is related to the crustal thinning that occurs south of the Ringkoebing-Fyn High. Hopefully future seismic work can resolve this question.

\section{Acknowledgements}

The perfect operation of both land and seacrews (R.V. "Poseidon" from the Institut for Meereskunde of the University of Kiel) provided the basis for this study. Helpfull comments and reviews of the manuscript by $C$. Andersen, $H$. Benz, A. Berthelsen, S. Gregersen, R. Meissner, and R. Roberts are much appreciated. G. Reim assisted in drawing the figures and M. KurpielaGeuther typed the manuscript. This research was funded by the Deutsche Forschungsgemeinschaft (grants Me 335/72-1, Fl 147/1-2 and Fl 147/1-3).

\section{References}

Berckhemer, H., 1970. Mars 66-Eine Magnetbandapparatur für seismische Tiefensondierung. J. Geophys. 36: 501-518.

Bertelsen, F., 1980. Lithostratigraphy and depositional history of the Danish Triassic. Geol. Surv. Den., Ser. B, 4: 59 pp.

Best, G., Kockel, F. and Schöneich, H., 1983. Geological history of the southern Horn Graben. Geol. Mijnbouw, 62: $25-33$.

Bialas, J., 1987. Refraktionsseismische Messungen an Land unter Nutzung von Airgunsignalen. Diploma Thesis, University of Kiel, 104 pp.

Bittner, R., Trappe, H. and Matthiesen, H., 1987. Piggyback seismic experiments during deep crustal reflection surveys. Ann. Geophys., 5B: 381-388.

EUGENO-S Working Group, 1988. Crustal structure and tectonic evolution of the transition between the Baltic Shield and the North German Caledonides (the EUGENO-S Project). In: R. Freeman, A. Berthelsen and St. Mueller (Editors), The European Geotraverse, Part 4. Tectonophysics, 150: 253-348.

Flueh, E.R. and Berthelsen, A., 1986. Tectonic evolution and crustal structure in Denmark and sout-west Sweden. In: R. Freeman, St. Mueller and P. Giese (Editors), Third EGT Workshop: The Central Segment. European Science Foundation, Strasbourg, pp. 41-52.

Frost, R.T.C., Fitch, F.J. and Miller, J.A., 1981. The age and nature of the crystalline basement on the North Sea Basin. In: L.V. Illing and G.C. Hubson (Editors), Petroleum Geology of the Continental Shelf of North-West Europe. Heyden-Inst. of Petrology, London, chapter 2, pp. 43-57. 
Galson, D.A. and Mueller, St., 1986. An introduction to the European Geotraverse Project: first results and present plans, Part 1. Tectonophysics, 126: 1-30.

Green, C.M., Stuart, G.W., Lund, C.E. and Roberts, R.G., 1988: P-wave Crustal Structure of the Lake Vaennern Area, Sweden. In: R. Freeman, A. Berthelsen and St. Mueller (Editors), The European Geotraverse, Part 4. Tectonophysics, 150: 349-361.

Gregersen, S., Flueh, E.R. Moeller, C. and Hirschleber, H., 1987. Seismic data of the EUGENO-S Project. Department of Seismology, Danish Geodetic Institute, ISBN 87-7450016.

Holmsen, P., 1958. Alkalisyeniter of Oslo-feltests eruptivstamme i Danmarks dybere undergrund. Medd. Dan. Geol. Fören., 14: 61-62.

Jokat, W., 1986. Die Anwendung ausgewählter Filterverfahren auf synthetische und beobachtete seismische Weitwinkeldaten. PhD-Thesis, University of Kiel, 135 pp.

Jokat, W. and Flueh. E.R., 1987. On the use of aigun arrays for seismic refraction investigations of the crust. First Break, 5(12): 440-447.

Kioerboe, L., 1988. Seismisk modellering og tektonisk tolkning af Ringkoebing-Fyn Hoejderyggen. Thesis, Copenhagen Univcrsity, $90 \mathrm{pp}$.

Larsen, O., 1971. K/Ar age determinations from the Precambrian of Denmark. Geol. Surv. Denmark, Ser. 2, $97: 37$ pp.
Liboriussen, J., Ashton, P. and Thygesen, T., 1987. The evolution of the Fennoscandian border zone in Denmark. Tectonophysics, 137: 21-29.

Luetgert, J.H., 1988. User's manuel for RAY 84/R83 PLT: Interactive two-dimensional raytracing/synthetic seismogram package. U.S. Geol. Surv., Open File Rep., 88-238: 55 pp.

Michelsen, O., 1978. Stratigraphy and distribution of Jurassic deposits in the Norwegian-Danish Basin. Den. Geol. Unders., Ser. B, 2: $29 \mathrm{pp}$.

Michelsen, O. and Andersen, C., 1981. Überblick über die regionale Geologie und Tektonik Dänemarks. Z. Angew. Geol., 27: 171-176.

Moeller, C., 1987. Modellering og Tolkning af EUGENO-S, Profil 1. Thesis Copenhagen University, $86 \mathrm{pp}$.

Mueller, St. and Banda, E., 1983. The European Geotraverse Project. First Break, 1: 25-28.

Saxov, S., 1976. Gravity measurements in Central Jylland. Geod. Inst. Skr., Raekke 3, 42: 138 pp.

Sorgenfrei, T. and Buch, A., 1964. Deep test in Denmark. 1935-1959. Dan. Geol. Unders., Raekke 3, 146 pp.

Ziegler, P.A., 1982. Geological Atlas of Western and Central Europe. Shell Internatinale Petroleum Maatschappij, The Hague/Elsevier, Amsterdam, $130 \mathrm{pp}$.

Ziegler, P.A., 1984. Caledonian and Hercynian crustal consolidation of western and central Europe-a working hypothesis. Geol. Mijnbouw. 63: 93-108. 